\title{
MEDIA KONSULTASI ONLINE SEBAGAI ALTERNATIF UPAYA PENANGANAN MASALAH REMAJA
}

\section{ONLINE CONSULTING MEDIA AS ALTERNATIVE EFFORT TO SOLVE TEENAGER PROBLEM}

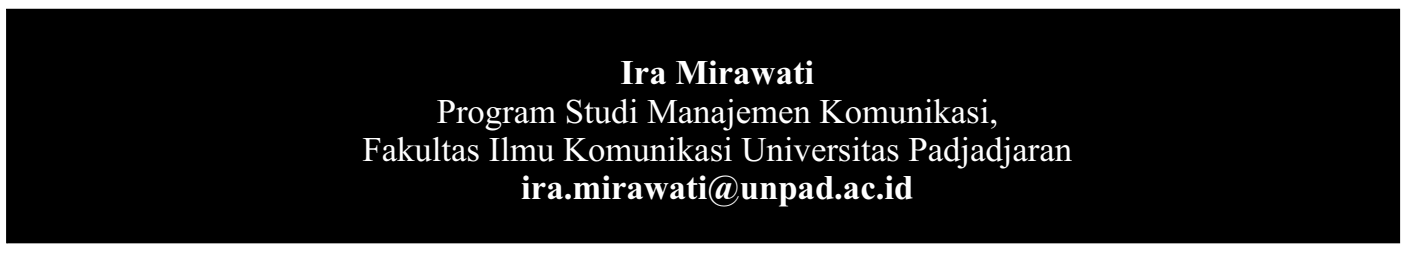

Abstrak. Kebutuhan remaja saat ini terhadap bimbingan karir dan konseling semakin tinggi, seiring dengan semakin beragamnya permasalahan remaja. Di sekolah-sekolah, kebutuhan konsultasi juga meningkat terutama sejak adanya Seleksi Nasional Masuk Perguruan Tinggi (SNMPTN) yang menggunakan "jalur sekolah" atau jalur prestasi. Masalahnya, karena berbagai sebab, ternyata tidak semua remaja dapat mengungkapkan permasalahan atau berkonsultasi dengan mudah secara tatap muka. Di sisi lain penggunaan media social di kalangan remaja meningkat dengan pesat, dari 88,1 juta orang pengguna internet yang dirilis oleh Asosisasi Penyedia Jasa Internet Indonesia, 58,4\% di antaranya adalah generasi muda, termasuk remaja. Oleh karena itu, adalah langkah yang tepat untuk menyediakan media konsultasi online yang dapat membuat para remaja dapat mengkonsultasikan permasalahan yang dihadapinya di manapun dan kapanpun. Penelitian ini berusaha mendeskripsikan kebutuhan para remaja di kota Bandung terhadap media konsultasi online, lalu mengembangkan prototype media konsultasi online berdasarkan deskripsi kebutuhan tersebut. Hasil penelitian menunjukkan bahwa di luar bimbingan karir, masalah yang dihadapi remaja di kota Bandung di antaranya adalah masalah pertemanan, masalah percintaan, masalah keluarga, dan masalah keuangan. Pada umumnya remaja menceritakan permasalahannya pada teman mereka, bukan pada keluarga atau guru/dosen

bimbingan dan konseling. Sebagian besar responden pernah mem-posting permasalahan mereka di media sosial, hanya untuk pelepasan tekanan, tanpa mengharapkan feedback dari teman atau follower mereka. Hampir seluruh responden tertarik untuk mencoba jika ada layanan konsultasi online. Mereka berharap, meskipun online, konsultasi tetap dapat dilakukan secara personal tanpa

muncul di ranah yang dapat dibaca oleh orang lain, dan jangan sampai permasalahan mereka diceritakan ke publik, meskipun namanya disamarkan. Selain itu, para responden menyarankan agar media konsultasi online tersebut menggunakan nama yang dekat dengan kehidupan remaja, bukan nama formal yang mencerminkan kelembagaan. Berdasarkan hasil penelitian tersebut, maka peneliti kemudian mengembangkan www.sobatmu.com sebagai media konsultasi online untuk pada remaja.

Kata kunci: Media Konsultasi Online, Bimbingan Konseling, Masalah Remaja 
Abstract. Nowadays, teenagers need for career guidance and counseling are increasing, along with the diversity of their problems. In the schools and universities, the need for consultation has also increased, especially since the University entrance examination using Seleksi Nasional Masuk Perguruan Tinggi (SNMPTN) known as "school path entrance". The problem is, for various reasons, not all teenagers can reveal or consult their problems using face to face communication easily. On the other hand social media user among adolescents increased rapidly. The latest data from Indonesian Internet Service Provider Association (APJII), indicate that 49\% from 88.1 million Indonesian internet users are adolescent. Therefore, it is the right step for us to provide online consultation media which can help them to consult the problems, anytime and anywhere. This research objectives are to describe the teenagers need of online consultation media, and develop its prototype. The results showed that beside of career guidance, the teenager problems are about friendship, love, family, and financial. Most respondents had posted their problems in social media, just to release the pressure, without expecting feedback from friends or their followers. Almost all respondents are interested to use online consultation service. They hope, the online consultations can be done personally and privately, without the ability of another internet user to read their consultation history. In addition, respondents suggested that online consultation media name using a popular name, close to the life of a teenager, not using a formal name that reflects the institution. Based on these results, we then developed www.sobatmu.com as online consultation media for teenagers.

Keywords: Online Consulting, Counseling, Teenager Problem 


\section{A. Pendahuluan}

sosiasi Penyedia Jasa Internet
Indonesia (APJII) menyatakan
bahwa pengguna internet di Indonesia kini telah mencapai angka 88,1 juta. Dengan demikian, jika disesuaikan dengan jumlah populasi penduduk Indonesia yang menurut data Badan Pusat Statistik (BPS) mencapai 252,5 juta jiwa, maka pengguna internet di Indonesia mengalami pertumbuhan 16,2 juta jiwa dari total 71,9 juta pengguna di tahun 2013. Dari jumlah tersebut, $49 \%$ diantaranya berada pada rentang usia 18 s.d. 25 tahun. Di sisi lain, sebuah data yang menarik dipaparkan oleh Juju Masunah dalam policy brief Pusat Penelitian dan pengembangan Kependudukan Universitas Pendidikan Indonesia, yang berjudul "Profil Pendidikan, Kesehatan, Dan Sosial Remaja Kota Bandung: Masalah Dan Alternatif Solusinya" (2011). Dalam tulisannya tersebut Masunah memaparkan berbagai permasalahan yang terjadi pada remaja di kota Bandung. Populasi remaja Kota Bandung, pada data sensus terakhir, yakni usia 10-24 tahun, adalah 28,55\% dari total populasi, yaitu sekitar 665.252 jiwa (BPS, 2011). Jumlah tersebut terdiri dari 345.975 remaja laki-laki dan 319.277 remaja perempuan.

Permasalahan tersebut, menurut Masunah meliputi masalah pendidikan, di mana menurut data Dinas Pendidikan Kota Bandung menunjukkan banyaknya siswa putus sekolah, baik pada tingkat SMP maupun SMA. Masalah berikutnya adalah masalah kesehatan, yang meliputi gangguan haid menduduki peringkat tertinggi (73\%) untuk kasus kesehatan reproduksi remaja, diikuti oleh konsultasi kontrasepsi (15.18\%), penyakit menular seksual $(3,75 \%)$, masalah pacaran $(2,4 \%)$, seks pra nikah (2\%), dan HIV/AIDS (1,92\%).

Selain permasalahan pendidikan dan kesehatan, masalah lainnya adalah penyalahgunaan narkoba, disinyalir $40 \%$ dari pengguna narkoba di kota Bandung adalah remaja. Permasalahan lain yang fenomenal di kota Bandung adalah geng motor. Di luar itu, ada pula permasalahan pernikahan dini dan trafficking, yang juga harus ditangani.

Tingginya masalah pada remaja ini ini disebabkan oleh beragam hal, baik yang berhubungan langsung dengan akademik, maupun permasalahan lainnya. Pada remaja yang sedang menjalani pendidikan di perguruan tinggi, penyebab kegagalan atau permasalahan mereka dipengaruhi oleh latar belakang personal yang beragam, yakni usia, kondisi keluarga, dan lain sebagainya (Khoirunnisak dan Ikhwan, 2010). Beberapa hal yang menyebabkan para remaja ini tidak dapat menemukan solusi untuk permasalahan yang mereka hadapi diantaranya adalah karena biasanya ku- 
rang dekat atau takut berkomunikasi dengan orang tuanya. Selain itu, diluar konteks bimbingan atau konsultasi tentang karir, mayoritas remaja tidak berani berkonsultasi langsung dengan guru BK di sekolahnya atau di Universitas tempat mereka menimba ilmu.

Menghadapi permasalahan dan kesulitan berkonsultasi yang dihadapi para remaja, negara-negara maju telah lama mengembangkan media konsultasi online. Negara berkembang seperti Indonesia juga mulai mengadopsi cara tersebut, namun saat ini mayoritas bergelut dibidang konsultasi kesehatan untuk orang dewasa. Oleh karena itu, perlu dikembangkan sebuah media konsultasi online yang dapat memfasilitasi remaja dalam mencurahkan permasalahannya dan mendapatkan jawaban atan pencerahan dari konsultan yang relevan dengan permasalahannya tersebut.

Penelitian terdahulu seputar remaja telah dilakukan pada berbagai aspek, misalnya seperti yang dilakukan oleh Nisfiannor, yang meneliti tentang penerimaan kelompok sebagai salah satu fase penting dalam kehidupan remaja. Menurut hasil penelitian ini, terdapat hubungan yang kuat antara kemampuan remaja dalam mengelola emosi dengan penerimaan kelompok.

Penelitian lain dilakukan oleh Soeparmanto dkk, berjudul Pengetahuan Dan Kebutuhan Pelayanan Informasi
Kesehatan Reproduksi Remaja Dl Beberapa Kota Besar Dl Jawa menunjukkan bahwa Kebutuhan akan informasi tentang reproduksi termasuk perilaku seksual memang diperlukan oleh remaja, hanya bagaimana cara penyampaiannya masih perlu dipertimbangkan. Informasi kesehatan reproduksi diperoleh remaja dari orang tua, teman sebaya, guru BP (BK), pelajaran biologi, surat kabar, seminar,diskusi remaja, majalah dan TV. Cara penyampaian informasi yang diharapkan remaja adalah: diskusi, layanan hotline (telepon), konseling, melalui surat, melalui media: booklet, leaflet dan poster. Kemasan yang diinginkan sesuai dengan jiwa remaja. Orang yang diharapkan menyampaikan informasi adalah teman sebaya, guru, lembaga konsultasi remaja, orang tua, dokter, atau bidan. Materi mengenai: nilai-nilai moral, hukum, agama, perkembangan remaja, pergaulan remaja, perilaku seksual yang sehat, penyakit menular seksual, danobat-obatan terlarang.

Kebutuhan masyarakat saat ini terhadap konsultasi menggunakan media digital ditunjukkan oleh Kusmiyati dkk dalam penelitiannya yang berjudul Pemanfaatan Short Message Service Berbasis Seluler dalam Meningkatkan Pengetahuan dan Sikap terhadap Seks Pranikah pada Remaja (2011) yang menunjukkan bahwa sms memberikan pe- 
ngetahuan yang sama baiknya tentang pengetahuan para remaja tentang kesehatan alat reproduksi di Yogyakarta. Sesuai dengan paparan di atas, di era digital ini adalah penting untuk menyediakan sarana konsultasi online sebagai alternatif upaya penanganan masalah remaja. Dalam tulisan ini, akan dideskripsikan bagaimana kebutuhan remaja akan media konsultasi online tersebut, dan bagaimana peneliti berusaha mewujudkan prototipe media konsultasi online yang diharapkan.

\section{Metode Penelitian}

Penelitian ini dilakukan dengan menggunakan dua langkah, yakni langkah pertama membuat deskripsi kebutuhan media konsultasi online, dan langkah kedua adalah menyusun prototype media konsultasi online berdasarkan kebutuhan remaja akan media konsultasi online. Pada langkah pertama metode deskriptif digunakan untuk menjawab pertanyaanpertanyaan penelitian yang bersifat memahami atau menguraikan suatu peristiwa, yaitu bagaimana kebutuhan remaja terhadap media konsultasi online. Setelah deskripsi berhasil dibuat dengan menganalisis hasil kuesioner dari 42 orang responden dan Focus Group discussion bersama sepuluh mahasiswa bidang konsentrasi Communication Training And Consulting Fikom Unpad, maka langkah berikutnya adalah mengembangkan prototype media konsu- tasi online berdasarkan kebutuhan para remaja.

\section{B. Hasil dan Pembahasan}

Pada penelitian ini, mayoritas responden mulai memasuki tingkat remaja akhir, yakni berusia 18 s.d.21 tahun. Hal ini sesuai dengan data mengenai pendidikan mereka yang mayoritas adalah mahasiswa perguruan tinggi, mulai dari semester I hingga semester VII. Sementara itu, ada 28\% responden berusia 16-18 tahun, yakni remaja yang sudah menginjak SMA kelas 2 dan mahasiswa tahun ketiga. Sisanya, sebanyak 5\% adalah remaja yang baru menginjak bangku SMA.

Mayoritas responden yang sedang menempuh pendidikan di perguruan tinggi mengaku bahwa mereka uang saku mereka berkisar Rp 750.000 s.d. Rp 1.000 .000 per bulan. Sementara rata-rata responden siswa SMA mengaku uang saku masih diberi per minggu, di luar kebutuhan primer, antara Rp 100.000 s.d. Rp 150.000. Dengan uang saku ini, akses para remaja terhadap media online tidak menghadapi kendala. Ini karena sekarang banyak operator telepon seluler yang menawarkan paket-paket internet menarik dengan harga terjangkau untuk remaja. Misalnya kartu 3 yang menyediakan paket AON (Always On), meskipun paket internetnya sudah habis namun dapat mengakses facebook dan witter gratis selama satu tahun. 
Gambar 1.

Akun Media Sosial Yang Dimiliki Responden

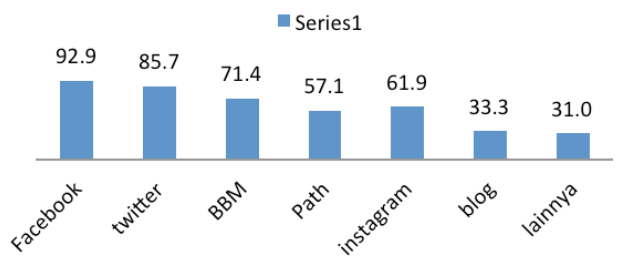

Hampir seluruh responden memiliki akun facebook, diikuti kemudian dengan twitter, BBM, instagram, dan path. Selain itu, ternyata meskipun era blog sudah dianggap meredup, $33,3 \%$ responden memiliki blog, yakni tumblr, blogspot, dan wordpress, namun tidak aktif dikelola. Media sosial lain yang digunakan diantaranya adalah line, ask.fm, dan wechat.

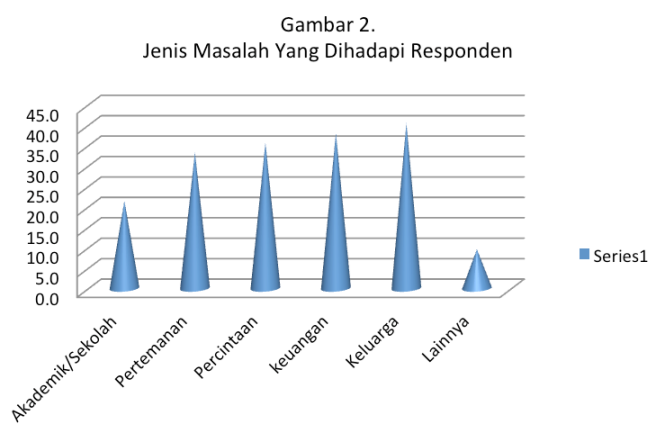

Dari jawaban responden, jenis masalah yang paling umum dihadapi oleh remaja adalah masalah keluarga. Di luar dugaan, ternyata masalah keuangan juga dihadapi oleh para remaja, dalam hal ini adalah para mahasiswa semester awal yang harus dapat mengelola uang bulanannya sendiri, padahal selama ini mereka banyak yang mendapat uang saku harian atau mingguan. Saat kuliah mereka harus mengelola uang saku sebulan, dan tidak dapat dengan mudahnya meminta tambahan saat keuangan menipis. Sebelum kuliah mereka hanya mengurus keuangan untuk kebutuhan sekunder dan tersier, sementara saat kuliah mereka juga harus mengurus keuangan untuk kebutuhan primer.

Masalah lainnya yang mereka hadapi adalah masalah percintaan, dalam hal ini adalah percintaan remaja seputar rasa suka, keinginan mendapatkan pacar, putus-sambung pacaran. Di luar itu, masalah pertemanan juga adalah sesuatu yang sering terjadi. Dan masalah yang justru tidak terlalu banyak dihadapi atau tidak dianggap sebagai masalah yang harus ditangani adalah masalah akademik atau belajar. Masalah lainnya meliputi masalah kesehatan, masalah pengembangan hobi, masalah pada kegiatan organisasi sekolah/kampus. Saat mendapatkan masalah, lebih dari setengah responden memilih menceritakannya pada teman. Teman dianggap sebagai orang yang paling dapat mengerti dan memahami duduk persoalannya. Teman dianggap sebagai pihak yang dapat memberikan solusi dan menemani disaat sedang membutuhkan "sandaran". Sebanyak 22\% responden memilih untuk menyimpan sendiri permasalahannya dan tidak menceritakan masalahnya pada siapapun. Mereka merasa permasalahan mereka tidak selesai meskipun dicerita- 
kan pada orang lain, oleh karena itu, daripada membuat orang tahu permasalahan mereka tanpa memberikan solusi berarti, para responden ini memilih untuk menyimpannya sendiri. Sementara itu, ada pula responden yang tidak menceritakan permasalahan mereka namun mencari solusinya sendiri secara aktif, dengan anggapan bahwa diri mereka sendirilah yang memahami permasalahan dan kunci penyelesaian permasalahan itu ada pada diri mereka seutuhnya. Yang mengejutkan, hanya $7 \%$ dari para responden yang menceritakan permasalahannya pada keluarga, baik itu orang tua maupun kakak dan adik mereka. Para responden enggan untuk menceritakan permasalahan mereka karena malu pada orang tua, takut orang tua merasa khawatir berlebihan, dan akhirnya menjadi overprotective terhadap pergaulan mereka. Untuk permasalahan di luar pencarian informasi tentang karir, ternyata BK sekolah atau universitas tidak menjadi pilihan bagi para remaja untuk mengadukan permasalahannya.

Kecenderungan remaja untuk menceritakan permasalahan kepada teman, sejalan dengan apa yang diungkapkan oleh Steinberg (2003) yang menyatakan bahwa remaja adalah masa di mana seseorang mengalami banyak perubahan secara kognitif, emosional, dan sosial.

Mereka mulai berpikir lebih kompleks, secara emosional lebih sensitif dan lebih sering menghabiskan waktubersama teman-temannya. Senada dengan itu, Furman dalam O'Koon (2000) menjelaskan bahwa hubungan antara remaja dan teman sebaya adalah hal yang utama dalam perkembangan remaja. Karena pada saat itu remaja berharap bisa mandiri, tidak dihubungkan lagi dengan orang tua. Remaja lebih membutuhkan dukungan dari teman-temannya dibandingkan dengan orang tua.

Berkaitan dengan penggunaan media sosial. Seperti sudah peneliti prediksi sebelumnya, karena akses para remaja terhadap media sosial sangat tinggi, maka mereka kemungkinan pernah menceritakan permasalahan mereka di media sosial, ternyata sebagian besar (71\%) memang pernah menceritakan nermasalahan mereka di media social

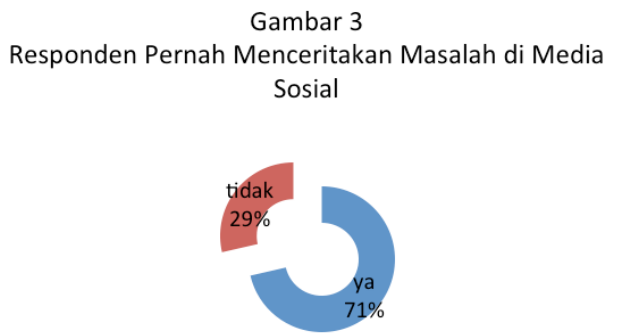

Dalam FGD diketahui bahwa media social yang paling cocok dijadikan untuk jadi tempat "curcol" atau curhat colongan, adalah facebook dan twitter. Bagaimana bentuk curhat yang biasanya dilakukan remaja melalui media sosial? Ternyata bukan uraian panjang lebar mengenai masalah mereka, melainkan terselubung dalam berbagai bentuk posting. Mulai dari mem-posting kalimat 
yang tidak menunjukkan permasalahan secara langsung, posting potongan syair lagu yang sesuai, atau memposting quotes yang sesuai.

Berikut ini contoh posting-an curhat para remaja di media social:

(a)astridasxxx : hidung mampet, kepala puyeng, tensi rendah banget. Heuu kenapa kamujadi lemah begini astrid?

@,Arlivxxx : wanita diuji ketika lelaki tak punya apa-apa, lelaki diuji ketika wanita tidak memakai apa-apa, dan teman diuji ketika kita lagi ada apa-apa.

Remaja juga mengungkapkan permasalahan ini melalui sebuah lagu:

(a)Ciedxxx: Oh Kasih kamu tak pernah tahu betapa sakitnya aku...

Contoh remaja yang mengungkapkan permasalahan dengan memposting atau meretweet quotes:

@illumixxx: if you don't fight for what you want, don't cry for what you lost.(retwweted by Tomxx)

Saat remaja mem-posting atau meretweet sebuah lagu dan quotes, maka ada dua kemungkinan, yakni dia sangat suka dengan lagu atau quotes tersebut meskipun tidak terjadi pada dirinya, atau apa yang ada di lagu dan quotes tersebut sedang terjadi padanya mungkin juga mewakili dirinya.

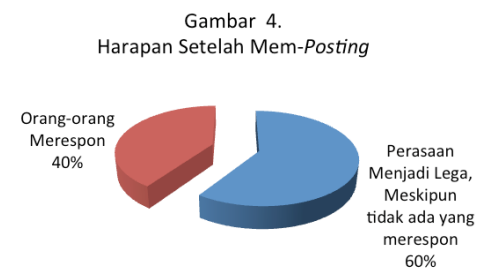

Mayoritas responden ternyata memposting status yang berkaitan dengan permasalahan mereka tidak terlalu berharap ada respon aktif dari teman dan followernya. Memposting permasalahan di media sosial dirasa sebagai sarana katarsis atau pelepasan diri dari tekanan. Dengan mengungkapkan permasalahan mereka dalam berbagai bentuk tulisan, baik itu berupa kalimat curahan hati, lirik lagu, dan juga lewat quotes, mereka sudah merasa lega.

\section{Ketertarikan Responden Pada Layanan Konsultasi Online}

Ketika ditanyakan pada responden apakah mereka tertarik dan ingin mencoba berkonsultasi jika ada layanan konsultasi online?, hampir semua responden menjawab bahwa mereka tertarik dan ingin mencoba untuk berkonsultasi.

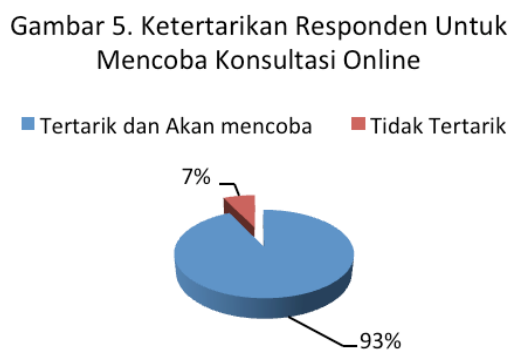

Dari FGD, diketahui bahwa ketertarikan para remaja terhadap media konsultasi online ini karena dari pada masalah itu mereka pendam sendiri, maka tidak ada salahnya untuk menceritakan permasalahan mereka pada orang yang ahli di bidang permasalahan tersebut. Apalagi jika tidak ada resiko "bocornya" permasalahan tersebut. Apalagi karena 
online, maka curhatnya bisa dilakukan kapan pun dan di mana pun tanpa diketahui orang lain.

Jika ada layanan konsultasi online, para remaja berharap mereka dapat mengkonsultasi permasalahan remaja, permasalahan keuangan, percintaan, pertemanan, pendidikan, serta sex dan kesehatan.

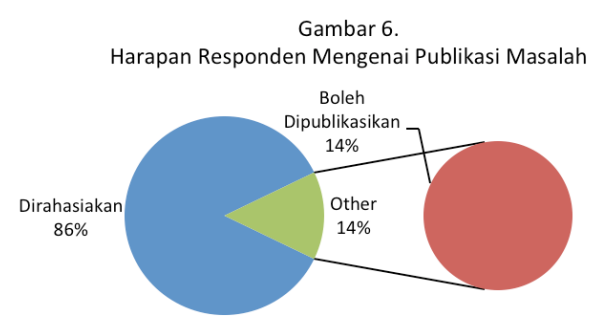

Pada umumnya para remaja berharap, jika mereka mengkonsultasikan masalah mereka, maka permasalahan itu harus sangat dijaga kerahasiaannya. Mereka tidak ingin masalah tersebut dipublikasikan, meskipun nama dan lokasi sudah disamarkan. Menurut mereka, permasalahan itu hanya untuk diketahui oleh diri mereka sendiri dan konsultan. Oleh karena itu, konsultasi sebaiknya dilakukan dengan fasilitas yang berupa jaringan pribadi atau direct message antara remaja dan konsultannya. Hanya ada 14\% remaja yang memperbolehkan masalahnya dipublikasikan setelah nama dan lokasi disamarkan, itu pun atas seizin mereka.

Responden mengaku lebih menyukai nama website yang "gaul" dan dekat dengan dunia remaja. Dalam FGD, peneliti menawarkan contoh nama-nama berikut: www.konsultasiremajaonline.com, www.konsultasiunpad.com. www.curhat.com, www.sobatmu.com. Akhirnya, Para peserta FGD memilih www.sobatmu.com, karena sobatmu ini menurut mereka unik, merupakan akronim dari "sahabat obrol atasi masalahmu"

\section{Membangun "Sobatmu" sebagai Prototipe Media Konsultasi Online}

Setelah menentukan nama, tahap berikutnya adalah pembuatan logo. Untuk dapat membuat logo, tim meminta bantuan kepada mahasiswa yang menguasai aplikasi desain grafis. Berikut ini logo yang dipilih oleh para informan FGD:

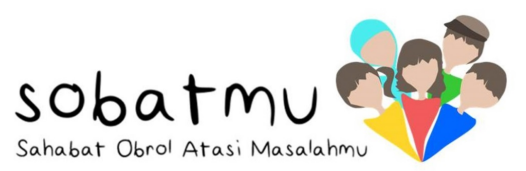

Gambar 7. Logo sobatmu.com

Menurut mereka, warna-warna yang digunakan cerah mewakili dunia remaja yang seharusnya ceria. Faceless icon digunakan untuk menggambarkan remaja yang bingung dengan permasalahannya, namun jika mereka bersama maka permasalahan akan terurai.

Setelah menentukan logo, maka langkah berikutnya adalah peneliti mengontak developer website untuk mewujudkan website yang direncanakan. Pilihan developer kemudian jatuh pada 
Smuufy, web designer \&developer yang berkantor di jalan Raden Fatah, Bandung, ini telah terbiasa membangun website berbagai lembaga dan bisnis online. Hasil penelitian deskriptif dan keinginan akan bentuk website yang sesuai untuk konsultasi online remaja didiskusikan dengan M. Yusuf Adiwiyarso, ST, yang menggawangi lembaga pengembangan website professional ini.

Berikut ini adalah halamanhalaman sobatmu.com:

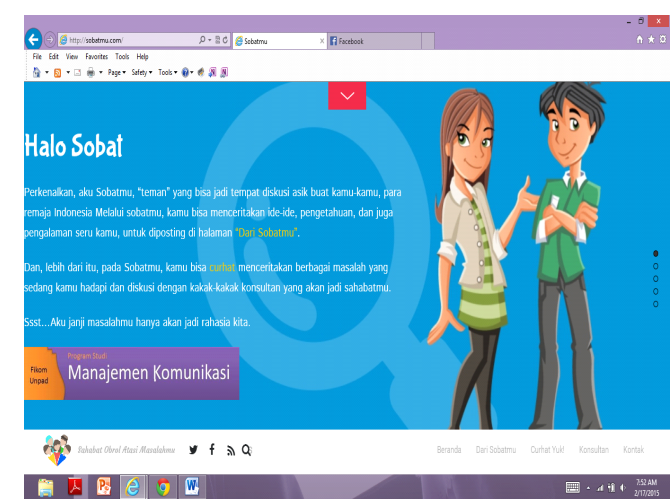

Gambar 8 .

Halaman depan www.sobatmu.com

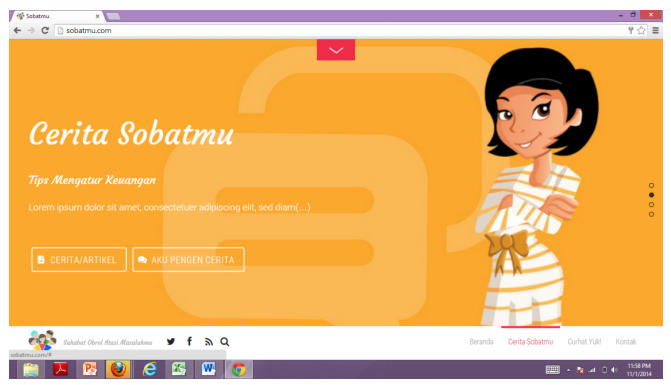

Gambar 9. Halaman untuk menceritakan atau mengirim artikel untuk dimuat di www.sobatmu.com

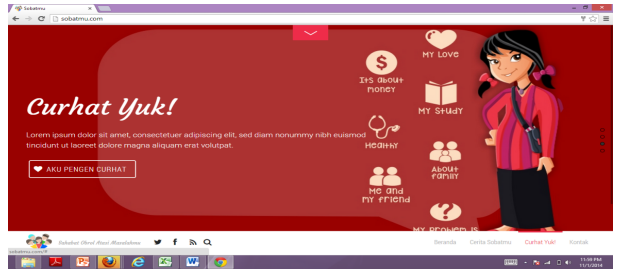

Gambar 10. Halaman untuk login kea kun pribadi dan melakukan konsultasi

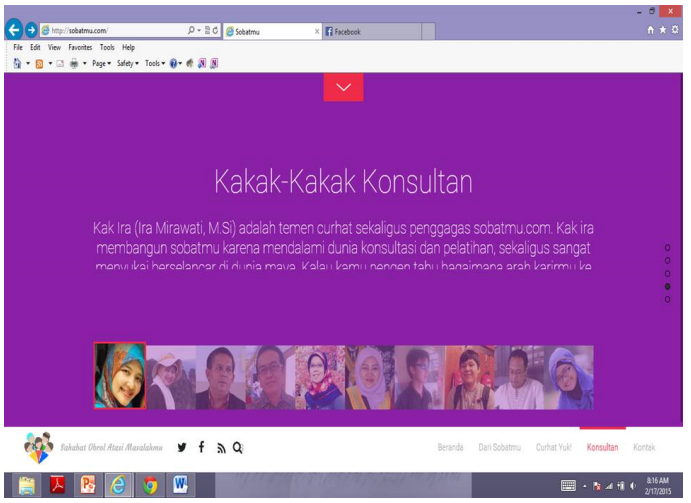

Gambar 11. Konsultan www.sobatmu.com

\section{Kesimpulan dan Saran}

1. Kesimpulan

Hasil penelitian menunjukkan bahwa masalah yang dihadapi remaja di kota Bandung di antaranya adalah masalah pertemanan, masalah percintaan, masalah keluarga, dan masalah keuangan. Pada umumnya remaja menceritakan permasalahannya pada teman mereka, bukan pada keluarga atau guru bimbingan dan konseling. Sebagian besar responden pernah mem-posting permasalahan mereka di media social, hanya untuk pelepasan tekanan, tanpa mengharapkan feedback dari teman atau follower mereka. Hampir seluruh responden tertarik untuk mencoba jika ada layanan konsultasi online. Mereka berharap, meskipun online, konsultasi tetap dapat dilakukan secara personal tanpa muncul di ranah yang dapat dibaca oleh orang lain, dan jangan sampai permasalahan mereka diceritakan ke publik, meskipun namanya disamarkan. Selain itu, para responden 
menyarankan agar media konsultasi online tersebut menggunakan nama yang dekat dengan kehidupan remaja, bukan nama formal yang mencerminkan kelembagaan.

Berdasarkan hasil penelitian tersebut, maka peneliti kemudian mengembangkan www.sobatmu .com sebagai media konsultasi online untuk pada remaja. Sobatmu adalah singkatan dari "Sahabat Obrol Atasi Masalahmu". Agar para remaja menyukainya website ini dirancang dengan tampilan, icon, dan warna-warna background cerah yang menarik. Untuk berkonsultasi para remaja akan memiliki dashboard pribadi berisi profil mereka serta riwayat konsultasi yang rahasia karena hanya dapat dibuka dengan username dan password mereka. Konsultan remaja di website ini adalah dosen-dosen berpengalaman di bidang permasalahan remaja yang dipanggil dengan "Kak" bukan "Ibu" atau "Bapak", agar remaja merasa dekat.

\section{Saran}

Setelah website konsultasi online "sobatmu" berhasil dibangun dan dijalankan, maka hendaknya dapat dilakukan uji coba kepada remaja kota Bandung untuk mengetahui bagaimana apresiasi atau sikap mereka terhadap website ini. Peneliti juga tidak berkeberatan jika ada dosen lain yang ingin melakukan pengabdian berbentuk sosialisasi website sobatmu ini kepada para remaja tidak hanya di kota Bandung namun juga kotakota lain di Indonesia, karena sebenarnya jangkauan media online ini tidak terbatas hanya di kota Bandung.

\section{Daftar Pustaka}

Khoirunnisa, Nur Iriawan .2010. Pemodelan Faktor-Faktor yang Mempengaruhi Mahasiswa Berhenti Studi (drop out) di Institut Teknologi Sepuluh Nopember Menggunakan Analisis Bayesian Mixture Survival.Surabaya: ITS

Kusmiyati, Yuni, Hari Kusnanti, Mohammad Hakimi, Berita Kedokteran Masyarakat, Volume 23

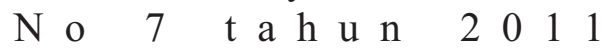
http://www.journal.ugm.ac.id/inde x.php/bkm/article/view/3403

Maulana, Adhi, 26 Maret 2015, Jumlah Pengguna Internet Indonesia Capai 881 Juta diakses melalui http://tekno.liputan6.com/read/219 7413/jumlah-pengguna-internetindonesia-capai-881-juta

Nisfiannor, 2004, Hubungan Antara Regulasi Emosi dan Penerimaan Kelompok Teman Sebaya Pada Remaja, Jurnal Psikologi Volume 2 Nomor 2 tahun 2004: Universitas Esa Unggul.

O'Koon, J, 2000, Attachment to Parents and Peers in Late Adolescence and Their Relationship with Self Image, melaluihttp://www.ncbi.nlm .nih.gov/pubmed/9179343 Perilaku Delinkuen Pada Remaja, Jurnal Psikologi Universitas Diponegoro Volume 3 Nomor 1 tahun 2006 
Soeparmanto, Palman, Imam Waluyo, Nella Ramdhani, 2001 , Pengetahuan dan Kebutuhan Pelayanan Informasi Kesehatan Reproduksi Remaja di Beberapa Kota Besar di Jawa, Buletin Penelitinan Kesehatan, Volume 4 No 1 Juni 2001

Steinberg, Laurence, 2003, in J. Kagan (Ed) Gale Encyclopedia Childhood and Adolescence, melalui http://www.encyclopedia.com/topi c/Peer_pressure.aspx 